\title{
Bahaya Obat Kiral Bisa Dihindari Dengan "Molecularly Imprinted Polymer"
}

\author{
Aliya Nur Hasanah \\ Fakultas Farmasi, Universitas Padjadjaran, Sumedang, Jawa Barat \\ Terbit online : 6 Desember 2016
}

\section{Abstrak :}

Obat memiliki sifat kiral. Pemisahan enansiomer untuk molekul kiral merupakan hal penting, terutama untuk industri farmasi, karena enansiomer dapat memiliki aktivitas farmakologi dan toksisitas yang berbeda. Peneliti berupaya menemukan metode dan tehnik untuk memisahkan obat-obat kiral sehingga diperoleh kemurnian yang tinggi. Penemuan metode baru terus dilakukan, salah satunya adalah Molecular imprinting polymer (MIP). Penggunaan MIP yang berkembang untuk pemisahan kiral masih membuka banyak peluang untuk aplikasi material ini sebagai fase diam dalam kromatografi cair kinerja tinggi (KCKT) maupun capillary electrochromatography (CEC).

Keyword: Oba kiral, enansiomer, Molecular imprinting polymer

\section{Pendahuluan}

Seperti yang sama-sama diketahui, obat memiliki sifat kiral. Pemisahan enansiomer untuk molekul kiral merupakan hal penting, terutama untuk industri farmasi, karena enansiomer dapat memiliki aktivitas farmakologi dan toksisitas yang berbeda. ${ }^{1}$

\section{Apa itu obat dengan molekul kiral?}

Molekul kiral adalah molekul yang mempunyai bayangan cermin tidak superimposabel (tidak dapat bertumpukan). Suatu molekul organik disebut molekul kiral jika terdapat minimal 1 atom $C$ yang mengikat empat gugus yang berlainan.

\section{Bencana thalidomid, reaksi senyawa kiral S-thalidomid yang tidak diinginkan}

Tragedi yang sangat mungkin masih dikenang banyak orang, yang dikenal dengan "bencana thalidomid" dimana terjadi ribuan bayi lahir dengan tungkai yang terbentuk tidak sempuma karena penggunaan yang tidak tepat S-thalidomid pada wanita hamil. ${ }^{2}$

Semua peneliti kemudian berupaya menemukan metode dan tehnik untuk memisahkan obatobat kiral sehingga diperoleh kemurnian yang tinggi. Baru pada tahun 1980, ditemukan metodemetode tersebut. Sejak saat itu, kromatografi cair kinerja tinggi (KCKT) menjadi pendekatan yang sering digunakan untuk pemisahan kiral, dan akhir-akhir ini diikuti dengan penggunaan capillary electrochromatography (CEC)..$^{3-7}$ 


\section{Penemuan metode baru pemisahan senyawa kiral}

Molecular imprinting polymer (MIP) pertama kali digunakan sebagai fase diam pemisahan kiral pada tahun 1970 oleh Wulff. Keuntungan dari MIP sebagai fase diam pemisahan kiral adalah afinititas dan selektivitas yang tinggi terhadap molekul target. Selain itu, biaya produksi dari MIP juga relatif rendah. Keuntungan ini yang kemudian meningkatkan penggunaan MIP. ${ }^{8}$

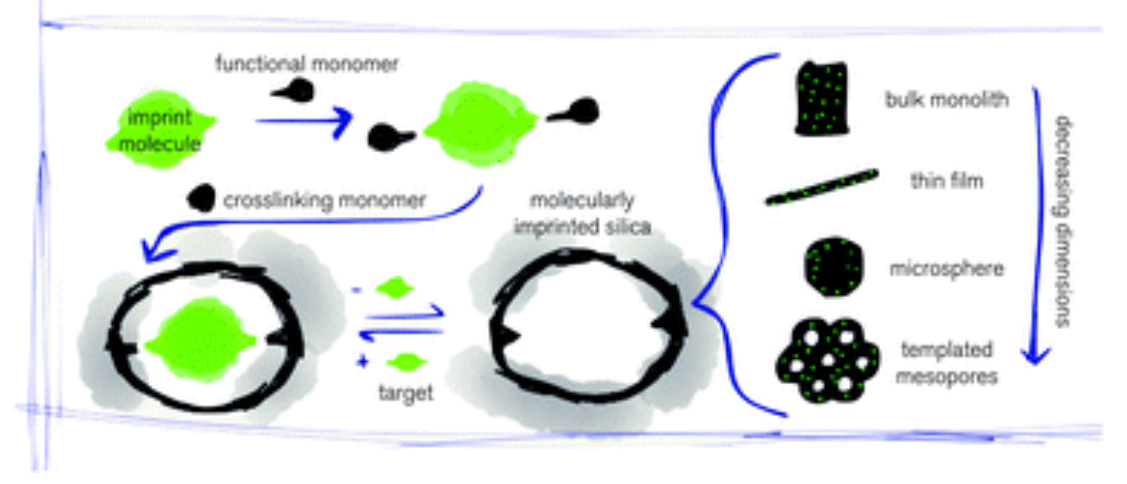

\section{Gambar 1. Cara Pembuatan MIP.9}

Seperti pada Gambar 1, MIP dibuat memlui proses pencampuran molekul template dengan monomer fungsional. Monomer fungsional mengandung gugus fungsi $Y$, yang kemudian akan mengalami reaksi pengikatan silang dengan pengikat silang (cross-linker)yang cocok, kemudian ruang tiga dimensi polimer akan terbentuk, dimana molekul template dikelilingi oleh monomer. Setelah itu molekul template akan dihilangkan dan meninggalkan ruang yang sama dengandengan molekul template dalam hal interaksi molekular, ukuran dan bentuk. ${ }^{8}$

Monolitik MIP telah digunakan secara ekstensif dalam KCKT untuk pemisahan kiral seperti untuk pemisahan S-ofloksasin, ketoprofen, S-citalopram.10 Matsui et al telah melakukan sintesis polimer MIP untuk fase diam pemisahan dengan metode in-situ. Dalam pembuatan MIP tersebut, senyawa template, monomer fungsional dan cross linker dicampur dalam kolom stainless steel dan dipanaskan untuk polimerisasi. Polimerisasi terjadi di dalam kolom sehingga menurunkan waktu untuk preparasi. Kolom untuk fase diam ini digunakan untuk pemisahan enansiomer turunan asam amino.

Penggunaan MIP yang berkembang untuk pemisahan kiral masih membuka banyak peluang untuk aplikasi material ini sebagai fase diam dalam KCKT maupun CEC. Usaha yang keras masih dibutuhkan untuk mendapatkan material pemisahan enansiomer berbasis MIP dengan selektivitas, efisiensi dan reprodusibilitas yang tinggi melalui pembuatan MIP dengan tehnik micro device, nanofibre dan partikel magnetik.

\section{Daftar Pustaka}

1. Fanali, S. Controlling enantioselectivity in chiral capillary electrophoresis with inclusioncomplexation.J. Chromatogr. A 1997, 792, 227-267

2. Kim, J.H.; Scialli, A.R. Thalidomide: The tragedy of birth defects and the effective treatment of disease.Toxicol. Sci. 2011, 122, 1-6

3. Okamoto, Y.; Ikai, T. Chiral HPLC for efficient resolution of enantiomers. Chem. Soc. Rev. 2008,37,2593-2608.

4. Ward, T.J.; Ward, K.D. Chiral separations: Fundamental review 2010. Anal. Chem. 2010, 82, 4712-4722.

5. Huang, Y.P.; Liu, Z.S.; Zheng, C.; Gao, R.Y. Recent developments of molecularly imprinted polymer in CEC. Electrophoresis 2009, 30, 155-162. 
6. Al-Othman, Z.A.; Al-Warthan, A.; Ali, I. Advances in enantiomeric resolution on monolithic chiralstationary phases in liquid chromatography and electrochromatography. J. Sep. Sci. 2014,37,1033-1057.

7. lacob, B.C.; Bodoki, E.; Oprean, R. Recent advances in capillary electrochromatography using molecularly imprinted polymers. Electrophoresis 2014, 35, 2722-2732.

8. Vasapollo, G.; Sole, R.D.; Mergola, L.; Lazzoi, M.R.; Scardino, A.; Scorrano, S.; Mele, G. Molecularly imprinted polymers: Present and future prospective. Int. J. Mol. Sci. 2011, 12, 5908-5945.

9. Lofgreen, J.E.; Ozin, G.A. Controlling morphology and porosity to improve performance of molecularly imprinted sol-gel silica. Chem. Soc. Rev. 2014, 43, 911-933

10.Dong, H.; Zheng, M.; Ou, Y.; Zhang, C.; Liu, L.; Li, J.; Yang, X. A chiral stationary phase coated bysurface molecularly imprinted polymer for separating 1, 10-binaphthalene-2, 20 diamine enantiomer by high performance liquid chromatography. J. Chromatogr. A 2015, 1376, 172-176.

Artikel ini telah terbit secara online di http://farmasetika.com/2016/12/06/bahaya-obat-kiral-bisadihindari-dengan-molecularly-imprinted-polymer/ 